\title{
RELIGIEUSE PLURALITEIT EN WAARHEID: DIE HOOFSTROOM CHRISTELIKE RESPONS
}

\author{
D.J. Louw ${ }^{1}$
}

\begin{abstract}
SAMEVATTING
Ons kleiner wordende wêreld konfronteer ons met 'n pluraliteit van godsdienste en 'n daarmee korrelerende pluraliteit van aansprake op "waarheid". Hoe moet ons hierdie aansprake evalueer? Die antwoord wat die meeste Christene op hierdie vraag gee, ossilleer tussen eksklusivisme en inklusivisme. Hierdie standpunte word krities bespreek aan die hand van Karl Barth (konserwatiewe eksklusivisme), Hendrik Kraemer en Emil Brunner (liberale eksklusivisme) en Karl Rahner (inklusivisme). Daar word tot die slotsom gekom dat die standpunte van sowel die eksklusivis as die inklusivis uiteindelik mank gaan an die subjektiewe willekeur wat hulle juis wou vermy.
\end{abstract}

\section{ABSTRACT}

\section{RELIGIOUS PLURALITY AND TRUTH: THE MAINSTREAM CHRISTIAN RESPONSE}

Our shrinking world confronts us with a plurality of religions of which all claim to be "true". How should we evaluate these claims? The mainstream Christian response to this question oscillates between exclusivism and inclusivism. These responses are explained and evaluated with reference to Karl Barth (conservative exclusivism), Hendrik Kraemer and Emil Brunner (liberal exclusivism) and Karl Rahner (inclusivism). It is concluded that the responses of both the exclusivist and inclusivist boil down to the very subjective arbitrariness that they wish to avoid.

\section{INLEIDING}

Weens die snelle vooruitgang van vervoer- en kommunikasiemiddele is gelowiges ${ }^{2}$ vandag, moontlik meer as ooit tevore, bewus van die pluraliteit van godsdienste en die daarmee korrelerende pluraliteit van

1 Prof. D.J. Louw, Navorsingsgenoot, Departement Filosofie, Universiteit van die Vrystaat, Posbus 339, Bloemfontein 9300. Adres vir korrespondensie: Posbus 11281, Bendor Park, Polokwane 0699. E-pos: eh21@mweb.co.za.

2 Dit is gelowiges wat wel die vooruitgang in vervoer- en kommunikasiemiddele beleef. Sogenaamde "globalisasie" is nie vir almal 'n werklikheid nie. 
aansprake op "waarheid". Ons "kleiner" wêreld konfronteer ons met die probleem van verskillende godsdienste se botsende aansprake op waarheid. Watter godsdiens het nou gelyk in sy aanspraak op waarheid? Hoe behoort gelowiges te oordeel oor die religieuse tradisies van ander? Berus die waarheid van godsdienste nie maar uiteindelik op persoonlike voorkeur nie?

Die antwoord wat die meeste Christene op hierdie vrae gee, ossilleer (steeds) ${ }^{3}$ tussen eksklusivisme en inklusivisme. Hierdie standpunte of benaderings kan voorlopig en onderskeidelik as volg formuleer word in (a) soteriologiese terme, (b) pisteologiese terme en (c) formele terme: (i) Eksklusivisme: (a) Die mens kan verlossing, redding of heil slegs langs een spesifieke weg (soos voorgestel deur een spesifieke religieuse tradisie) deelagtig word; (b) Die mens kan slegs in en deur Christus verlossing, redding of heil deelagtig word; (c) Slegs een godsdiens is waar. Die res is almal misleidend; (ii) Inklusivisme: (a) Die mens kan verlossing, redding of heil langs 'n verskeidenheid van weë deelagtig word, maar al hierdie weë — in soverre hulle wel heilsweë is — val saam met die bepaalde weg van verlossing, redding of heil wat deur een spesifieke religieuse tradisie voorgestel word. Laasgenoemde weg dien as die norm of vervulling van eersgenoemde verskeidenheid van heilsweë; (b) Verlossing, redding of heil word oral in die wêreld op 'n verskeidenheid van maniere bewerkstellig, maar dit is altyd deur die toedoen van Christus; (c) Slegs een godsdiens is waar. Die res is waar in soverre hulle met die een ware godsdiens saamval. Die een ware godsdiens dien as die kriterium aan die hand waarvan elemente van waarheid in ander godsdienste geïdentifiseer sou kon word.

3 Christene volg 'n wye verskeidenheid van benaderings jeens die probleem van verskillende godsdienste se botsende aansprake op waarheid, waaronder benaderings wat nie saamval met wat hier as "eksklusivisme" en "inklusivisme" bestempel word nie (vgl. Louw 1995:1-171). Die feit dat laasgenoemde benaderings (of 'n kombinasie daarvan) egter voorveronderstel word deur Rick Warren se The purpose driven life (2002), wat oor die 20 miljoen (veral Gereformeerde) Christene tans wêreld wyd instemmend bestudeer, en die feit dat wat hier as die "inklusivistiese" benadering bestempel word, steeds die kern van die amptelike RoomsKatolieke standpunt in hierdie verband uitmaak, laat 'n mens sterk vermoed dat hierdie benaderings steeds met reg as hoofstroom Christelike benaderings beskou kan word. 
Dat die standpunte of menings van hoofstroom Christene saak maak, kan moeilik betwis word. Christene of Christelike groeperinge het byvoorbeeld steeds 'n beduidende invloed op die politieke bestel van state, ook sogenaamde sekulêre state. Dink maar aan die deurslaggewende steun van die "Religious Right" vir George W. Bush in die pas afgelope Amerikaanse presidentsverkiesing. Hierdie religieuse groepering sluit nie net die wye skakering van Protestante in wat as sodanig vir die Gereformeerde Bush gestem het nie. Dit sluit ook daardie Katolieke in vir wie die on-Katolieke beleidsrigtings van Bush se Katolieke opponent, John Kerry, een te veel was. 'n Mens dink hier byvoorbeeld aan Kerry se goedkeuring van aborsie op aanvraag, of aan sy steun vir die terapeutiese gebruik van embrionale stamselle.

Om egter relevant of belangrik te wees, is een saak; om krities verantwoordbaar te wees, totaal 'n ander. Presies hoe verantwoordbaar is die eksklusivistiese en/of inklusivistiese houding van Christene jeens ander godsdienste? Bied dit wel 'n houdbare alternatief op subjektiewe willekeur ten aansien van die botsende aansprake op waarheid van verskillende godsdienste? Wat volg, is 'n poging om 'n antwoord op hierdie vrae te bied. Die werk van Karl Barth, volgens vele die vader van die eksklusivistiese standpunt, sal eerste onder die loep geneem word. Daarna sal die eksklusivistiese-cum-inklusivistiese standpunte van die neo-Barthiane, Hendrik Kraemer en Emil Brunner, aan die beurt kom waarna 'n klassieke inklusivistiese standpunt — dié van die Katolieke teoloog, Karl Rahner - ten slotte beoordeel sal word. Ek hoop om aan te toon dat, benewens allerlei interne inkonsistensies, die standpunte van sowel die eksklusivis as inklusivis mank gaan aan die subjektiewe willekeur wat hulle juis wou vermy.

\section{EKSKLUSIVISME: BARTH}

Karl Barth ${ }^{4}$ se standpunt ten opsigte van die waarheid van godsdiens en van godsdienste kan in twee skynbaar teenstrydige stellings saamgevat word. Die eerste stelling lui dat alle godsdiens of religie ongeloof is. Die tweede stelling lui dat die Christelike godsdiens die enigste ware godsdiens is.

4 Vergelyk Barth (1956:280, 297-303, 307-310, 325-328, 332-333, 337-338, 353354), opgeneem in Thomas (1969:96-112), Hick \& Hebblethwaite (1981:32- 
Met die stelling dat alle religie "ongeloof" is, bedoel Barth dat religie as sodanig niks te leer het wat waar is nie. Hiermee bedoel hy dat religie nóg aan die mens insig bied in sy vervalle of sondige toestand, nóg die weg aandui waarlangs die mens verlos sou kon word uit hierdie toestand. Uit homself is die mens tot niks goeds in staat nie (vgl. Barth 1956:301 e.v.). Ware kennis van sonde en van verlossing van sonde val buite sy vermoë. Hierdie konklusie klop in die eerste plek met die historiese omstandighede waarin dit oorspronklik geformuleer is. Barth het hierdie konklusie teen die einde van die dertigerjare geformuleer, dit is met die tragedies van die Eerste Wêreldoorlog nog vars in sy geheue en tydens die opkoms van nog 'n groot tragedie van die vorige eeu, te wete die Nasionaal-sosialisme van Nazi-Duitsland. ${ }^{5}$ Genoemde konklusie klop volgens Barth egter ook met wat hy as die enigste norm vir waarheid beskou, te wete die genadige self-openbaring van God in Jesus Christus, soos vervat in die Nuwe Testament. Volgens Barth leer hierdie openbaring duidelik twee dinge. In die eerste plek leer dit dat slegs God Homself kenbaar kan maak, oftewel, enige ware kennis van God is resloos die resultaat van God se genadige selfopenbaring (Barth 1956:301). Hierdie kennis omvat ook Barth se eie kennis van God. Anders gestel, in soverre dit wat hy self oor God en die werk van God te sê het, waar is, is dit volgens Barth resloos die resultaat van God se genadige self-openbaring (vgl. Barth 1985:364). In die tweede plek leer hierdie openbaring volgens Barth duidelik dat slegs God die mens uit sy vervalle, sondige toestand kan verlos (1956:307). Hierdie verlossing geskied uitsluitlik in en deur die soenverdienste of "versoeningsverdienste" (dit is verdienste wat die mens met God versoen) van Jesus Christus. As sodanig geskied dit uitsluitlik uit genade en nie op grond van enige verdienste van die kant van die mens nie. Hierdie verlossing word nie en kan nie deur "goeie werke" ver-

51) en Hodgson \& King (1985:362-368). Ek konsentreer hier spesifiek op die standpunt van Barth soos uiteengesit in paragraaf 17 van sy Kirchliche Dogmatik I/2 (1938). Ek is egter bewus van die feit dat 'n vroeëre en latere fase in die standpunt van Barth ten opsigte van die waarheid van godsdiens en die godsdienste onderskei kan word, en dat die "latere" Barth (vgl. 1961:97, 355-356) nie sonder meer as 'n "eksklusivis" bestempel kan word nie. Vergelyk in hierdie verband Braaten (1992:49-63).

5 Vergelyk Kraemer (1956:357) en Braaten (1992:50-51). 
dien word nie. Alle "goeie werke", alle religie, is niks meer as "ongeloof” nie (Barth 1956:297 e.v.).

Hierbenewens is Barth egter ook van mening dat die Christelike godsdiens die enigste ware godsdiens is. Hiermee wil hy nie sê dat die Christelike godsdiens nie óók "ongeloof" is nie. Trouens, Barth stel dit duidelik dat ook die Christelike godsdiens as godsdiens aan afgodery en selfgeregtigheid skuldig is (vgl. 1956:327; 1985:365). Die Christen sou dus nie op grond van die meriete van die Christelike godsdiens as godsdiens kon aanvoer dat hierdie godsdiens (vis-à-vis ander godsdienste) waar is nie. Op grond waarvan sou die Christelike godsdiens dan wel as die enigste ware godsdiens beskou kon word? Hierop antwoord Barth dat die Christelike godsdiens die enigste ware godsdiens is omdat en in soverre God uit genade gekies het om uitsluitlik aan Christene "die waarheid" te openbaar, dit is om aan Christene te openbaar dat alle religie "ongeloof" is, dat slegs God God kan openbaar en dat slegs God die mens in en deur Jesus Christus van sy sonde kan verlos (vgl. Barth 1956: 325-327, 348, 356). Hierdie openbaring verander niks aan die "ongelowige" karakter van die Christelike godsdiens as godsdiens nie. As godsdiens bly die Christelike godsdiens steeds so "ongelowig" soos enige ander godsdiens. Om te verduidelik wat hy hiermee bedoel, vergelyk Barth hierdie genadige self-openbaring van God met die lig van die son (vgl. 1956:353; 1985:367). Die lig van die son val op 'n spesifieke gedeelte van die aarde en nie op ander gedeeltes nie (resp. God se selfopenbaring "val" uitsluitlik op die Christelike godsdiens en nie op ander godsdienste nie). Alhoewel dit dag is waar die lig van die son val, en nag is waar dit nie val nie, bly die aarde orals dieselfde (resp. soos ander godsdienste, bly die Christelike godsdiens steeds as godsdiens "ongelowig”. Die feit dat dit op 'n spesifieke gedeelte van die aarde dag is, is nie te danke aan enige inherente kwaliteite van daardie spesifieke gedeelte nie, maar aan die lig van die son). Hierdie begrip van die verhouding tussen God se self-openbaring en die Christelike godsdiens, verklaar ook Barth se reaksie op skynbare ooreenkomste tussen die Christelike godsdiens en ander godsdienste. Volgens hom is daar wel 'n merkwaardige ooreenkoms tussen die Christelike leerstelling dat die mens slegs "deur geloof" en "uit genade" gered kan word, en die leerstellings van Amida Boeddhisme en Bhakti Hindoeïsme (vgl. Barth 1956:340343). Steek daar dus tog waarheid in hierdie godsdienste? Hierop ant- 
woord Barth beslis ontkennend. Die waarheid van 'n godsdiens hang nie af van die ooreenkomste wat dit met die Christelike godsdiens vertoon nie. Alle godsdienste, ook die Christelike godsdiens, is “ongeloof”. Daar is slegs één norm vir waarheid, naamlik God se genadige self-openbaring in Jesus Christus. ${ }^{6}$ Die waarheid kan dus nie uit Christelike leerstellings, of uit enige ander religieuse leerstellings, afgelei word nie. Die waarheid word ontvang; dit is 'n geskenk uit genade en dit is as sodanig slegs aan Christene toevertrou (Barth 1956:339). Of, soos Paul Knitter hierdie fundamentele uitgangspunt van Barth formuleer:

There is a difference between the religious doctrine about grace and "the reality of grace itself". Only the reality of grace makes a religion true and valuable. And only Christianity, standing in the light of Christ, has this reality (Knitter 1985:86). ${ }^{7}$

\section{VAN EKSKLUSIVISME TOT INKLUSIVISME: KRAEMER EN BRUNNER}

Hiermee is genoeg gesê ter illustrasie van wat as die "konserwatiewe" eksklusivistiese benadering of standpunt bestempel kan word. Hierdie standpunt lui dat God Homself slegs aan Christene openbaar en tewens reddend openbaar. Op grond van hierdie feit, en slegs op grond van

6 Barth het dit dus nie teen nie-Christelike godsdienste per se nie. Hy het dit eerder teen die veronderstelling dat enige godsdiens, ook die Christelike godsdiens, as 'n norm vir waarheid sou kon dien (vgl. Lochhead 1988:34; Braaten 1992: 54-56).

7 Hierdie onderskeid, dit is tussen die "religious doctrine about grace" en die "reality of grace itself", val binne die konteks van Barth se denke saam met die onderskeid tussen "empirical Christianity" en "the revelation of Christ". Talle outeurs het egter reeds tereg daarop gewys dat hierdie onderskeid nie klop met die insig dat die self-openbaring van God in Christus nie anders as via die leerstellings van 'n religieuse tradisie (in hierdie geval die Christelike tradisie) aantrefbaar en kommunikeerbaar is nie. Só verstaan, maak die bewering dat God se self-openbaring in Jesus Christus die Waarheid is, terwyl die religieuse leerstelling insake hierdie openbaring onwaar of "ongeloof" (Barth) is, nie sin nie. Vergelyk in hierdie verband Race (1982:28 e.v.), Knitter (1985:140) en D’Costa (1986:74). Vergelyk ook Mulder (1989:17) se kritiek op die neo-Barthiaanse onderskeid wat Kraemer mak tussen, enersyds, "Bybelse realisme" en, andersyds, "die godsdienste van die wêreld". 
hierdie feit, kan gesê word (of, altans, so lui die standpunt) dat daar slegs één ware godsdiens is, te wete die Christelike godsdiens. Die "liberale" eksklusivistiese benadering of standpunt lui hierteenoor dat God se openbaring ook buite die Christelike godsdiens aangetref kan word, maar dat hierdie "buite-Christelike" openbaring van God nie ' $n$ reddende openbaring is nie. Hierdie standpunt kan aan die hand van 'n wye reeks Christelike (hoofsaaklik Protestantse) denkers illustreer word. ${ }^{8}$ Hendrik Kraemer is byvoorbeeld van mening dat God ook in die natuur, die geskiedenis, die gewete en deur die universele religieuse bewussyn van die mens werk (vgl. 1938:112-113, 120; 1956:171). Hierby merk Kraemer egter in één asem op dat alle "modi" van God se openbaring hul oorsprong, betekenis en norm in Jesus Christus vind

and that the revelation of God's righteousness in Christ is the final revelation in the light of which Jesus Christ is the Truth, the only Truth, without whom no man comes to the Father ... (1956:359; vgl. ook 1960:65 e.v.).

Geoordeel in die lig van hierdie norm (dit is God se self-openbaring in Jesus Christus)

all religious life, the lofty and the degraded, appear to lie under divine judgement, because it is misdirected. This is the dialectical "no" of the revelation in Christ to all religious life ... At the same time, however, this revealing light means a dialectical "yes", a comprehension of religion and the various religions that is deeper and more adequate than their understanding of themselves, because it uncovers the groping and persistent human aspiration and need for "the glory of the children of God" in the misdirected expressions of religious life (1938:136-137; vgl. ook 1938:126-127; 1956:350).

8 Waaronder Paul Althaus, Emil Brunner, Hendrik Kraemer, Lesslie Newbigin, Stephen Neill, Norman Anderson, Paul Devanandan, M.M. Thomas, Paul Tillich, Wolfhart Pannenberg, Carl Heinz Ratschow, Carl E. Braaten, Hans Urs von Balthasar, Jean Daniélou en Visser't Hooft (miskien eerder 'n konserwatiewe eksklusivis? - Vergelyk Mulder 1986:212). Ek wil nie sê dat hierdie figure slegs ter illustrasie van die liberale eksklusivistiese benadering gebruik sou kon word nie. Die werk van hierdie denkers/teoloë word verskillend geïnterpreteer. Ek wil daarom slegs sê dat hierdie figure ten minste óók ter illustrasie van genoemde benadering gebruik kan word. Vergelyk ook Knitter (1985:97 e.v.). 
Die invloed van Barth op die denke van Kraemer is duidelik. Kraemer beweeg egter weg van Barth in soverre eersgenoemde ook ander "modi" van God se openbaring identifiseer, dit is in soverre hy ook "ja" sê ten opsigte van godsdiens en die godsdienste. Soos ons gesien het, kan Barth se houding ten opsigte van godsdiens saamgevat word in 'n ondubbelsinnige "nee". Alle godsdiens, sê Barth, is "ongeloof" (dit is insluitende "empirical Christianity", maar uitsluitende die Christelike godsdiens soos "verlig" deur die genadige self-openbaring van God). Sonder om daarmee te sê dat die mens deur godsdiens "gered" sou kon word, stel Kraemer dit hierteenoor nietemin duidelik "that within the domain of the religions there are evidences of God's revealing activity" (1956: 348). Hierdie "dialektiese" houding (dit is 'n "ja" én 'n "nee") $)^{9}$ van Kraemer ten opsigte van religie en spesifiek ten opsigte van nie-Christelike religieë, mak hom 'n geesgenoot van Emil Brunner. ${ }^{10}$ Laasgenoemde (vgl. Brunner 1946:258-273) ${ }^{11}$ huldig 'n paradoksale standpunt. Enersyds wil dit voorkom asof hy ook, soos Barth, van mening is dat daar géén waarheid in religie, insluitende die Christelike religie, is nie. Anders gestel, soos Barth meen Brunner skynbaar ook dat daar buite God se genadige self-openbaring in Jesus Christus geen waarheid te vinde is nie. Hy skryf byvoorbeeld:

The Christian faith, faith in the God revealed by Jesus Christ, is not "one of the religions of the world". It cannot admit that its faith is one species of the genus "religion", or if it does so, only in the sense in which it regards itself as the true religion in contrast to other false

9 Vergelyk Thomas (1969:24-25). Vergelyk in hierdie verband ook Kraemer se kritiek op wat hy beskou as Barth se oorbeklemtoning van die "nee" ten opsigte van religie. Kraemer skryf:

One does not feel that this is dialectical theology! It keeps religion and religions in their place, but it establishes no contact and no real encounters (1956:193 — my klem; vgl. ook 1956:356).

Mulder is egter van mening dat ook Kraemer se teologie nie "dialekties" genoeg is nie:

[A]lthough he claims to look in a dialectical way at the reality of religions, in fact he has a negative view of them ... (1989:17).

10 Insake die aard en status van die "buite-Christelike", "universele" of "algemene" openbaring van God, was Kraemer dit egter ook nie met Brunner volledig eens nie. Vergelyk in hierdie verband Kraemer (1956:356-358) en Race (1982:17 e.v.).

11 Opgeneem in Thomas (1969:115-132). 
religions (1969:115-116); For in Jesus Christ "the Christian religion" is judged as much as the other religions ... "True religion" can therefore consist only in the fact that our trust is not in "religion" at all but wholly and solely in that divine mercy which meets us in God's revelation ... (Brunner 1969:131).

Andersyds stel Brunner dit in sy sogenaamde "dubbele" of "tweeledige" tese insake godsdienste duidelik dat daar tog elemente van waarheid in die godsdienste is, maar dat hierdie waarheid deur die sonde bederf is en word:

[T]he religions, the religious life of the natural man, are the product of the original divine revelation and of human sin (1969:120); In all religion there is a recollection of the divine truth ... but in all religion also there yawns an abyss of daemonic distortion of the truth, and of man's effort to escape from God (1969:123-124); it lies in the nature of sin that it even captures the highest in man (1969:132).

Hierdie uitsprake verwoord 'n fundamentele spanning in die liberale eksklusivistiese benadering. Enersyds word op tipies Barthiaanse wyse aangevoer dat Jesus Christus as die self-openbaring van God "the only Truth" (Kraemer) is. Andersyds word aangevoer dat daar tog waarheid in godsdiens en in die godsdienste is. Brunner skryf byvoorbeeld:

None [of the non-Christian religions - DJL $]^{12}$ is without its impressive truth, and yet none of them is the Truth; for their Truth is Jesus Christ (1969:129).

Wat presies, sou 'n mens nou egter tereg kon vra, is die verhouding tussen die waarheid soos geopenbaar in Jesus Christus en die waarheid wat volgens die liberale eksklusivis in godsdiens en die godsdienste gevind kan word? Een ding is seker: vir die liberale eksklusivis is laasgenoemde waarheid geen reddende waarheid nie. Dit is juis die punt wat Brunner se tweeledige tese insake die waarheid van godsdienste wil maak (vgl. ook Knitter 1985:102). Selfs die Christen se vroomheid, sê Brunner, "needs the forgiving grace of Christ" (1969: 131; vgl. ook 1969:130). Soms word gesê dat Jesus Christus die "Vervuller" is van die waarheid van godsdiens en die godsdienste:

12 Presies dieselfde aanspraak word 'n paar paragrawe later ten opsigte van "all religious systems” (Brunner 1969:130 — my klem) gemaak. Bygesê: dis nie altyd duidelik of Brunner dit spesifiek oor nie-Christelike godsdienste het en of hy dit oor godsdiens as sodanig het nie. 
As the Fulfiller, He is the Truth which ... religions seek in vain. There is no phenomenon in the history of religion that does not point toward Him ... (Brunner 1969:129).

Verwysings na Jesus Christus as die "Vervuller" van die waarheid van godsdiens en die godsdienste word egter spoedig gekwalifiseer met:

From the standpoint of Jesus Christ, the non-Christian religions seem like stammering words from some half-forgotten saying ... Jesus Christ is not only the Fulfillment; He is also the Judgement on all religion. Viewed in His light, all religious systems appear untrue, unbelieving, and indeed godless (Brunner 1969:129-130).

Hierdie uitspraak laat 'n mens wonder of daar nog enigsins betekenisvol van 'n kontinuitteit tussen Jesus Christus as die Waarheid en die waarheid van godsdienste sprake kan wees. Sonder hierdie kontinuïteit sou Jesus Christus beswaarlik as die "Vervuller" van die waarheid van godsdienste beskou kon word. Kraemer stel dit trouens duidelik dat die Waarheid (dit is Jesus Christus) diskontinu is met die waarheid van godsdienste, en dat "vervulling" daarom hier as "transposal" (dit is verwisseling, verplasing, vervanging) gelees moet word:

[I]f one accepts the revelation [dit is God se self-openbaring in Jesus Christus] as the only criterion for Truth — then to think systematically in terms of "continuity" as to the relation of the Christian faith [dit is die Christelike godsdiens soos "verlig" deur God se selfopenbaring in Jesus Christus] to the non-Christian religions is selfdefeating and self-contradictory ... "My thoughts are not your thoughts, neither are your ways my ways, saith the Lord" (Kraemer 1956:351; vgl. ook Newbigin 1988:329).

Die vraag is nou egter: indien Jesus Christus inderdaad die enigste Waarheid is, en indien hierdie Waarheid diskontinu is met die waarheid wat na bewering in die godsdienste aangetref kan word, in watter sin sou die godsdienste dan nog met reg as "waar" bestempel kon word? Wat die antwoord van Brunner, Kraemer en ander liberale eksklusiviste op hierdie vraag sou (kon) wees, is nie vir my duidelik nie.

Sowel die liberale as die konserwatiewe eksklusivistiese benadering toon egter ook 'n ander ernstige anomalie. Sowel die liberale as die konserwatiewe eksklusivistiese Christen huldig die standpunt dat God Homself uitsluitlik in en deur Jesus Christus reddend geopenbaar het en dat redding of "verlossing van sonde" daarom slegs via geloof in die soenverdienste van Jesus Christus verkry kan word. Hierdie stand- 
punt impliseer noodwendig dat die oorgrote meerderheid van mense, sonder hul eie toedoen of sonder dat hulle self daarvoor verantwoordelik gehou kan word, verlossing van sonde misloop. Onder diegene tel byvoorbeeld mense wat voor die Christus-gebeure geleef het, of mense wat om een of ander rede nooit van Hom gehoor het nie. Soos Martin Prozesky tereg opmerk:

The trouble with mainstream [Christian] soteriology is that the kind
of salvific act which it says God performed, namely a unique incar-
nation in Christ alone requiring a conscious act of human accep-
tance, seems structurally incapable of helping all people on a fair basis.
There simply is no way that a life-line constructed and made available
in the form of a unique incarnation can possibly save more than the
minority who happen to be within reach of that life-line (1991:40-
41; vgl. ook Schroten 1984:312; Knitter 1985:116; D'Costa 1986:
67; Alberts 2002:45).

Sowel die liberale as die konserwatiewe eksklusivistiese Christen glo egter ook dat God almagtig en regverdig is, en dat Hy volmaakte liefde is. God "ons Verlosser... wil hê dat alle mense gered word en tot kennis van die waarheid kom" (vgl. 1 Timoteus 2:3-4). Nou is die vraag: klop hierdie oortuiging wel met die eksklusiewe soteriologie van eksklusiviste? Indien God wel almagtig, regverdig en volmaakte liefde is, dan sou 'n mens immers kon verwag dat Hy sou kon toesien, en dat Hy inderdaad sou toesien dat alle mense "gered" word, en nie slegs diegene wat "gelukkig" genoeg was om met Christus gekonfronteer te word nie. 'n Almagtige, volmaak liefdevolle en regverdige God sou Homself/Haarself ook op ander maniere as bloot via die inkarnasie reddend openbaar. Die veronderstelling dat dit wel die geval is, druis egter lynreg teen die eksklusivistiese Christelike soteriologie in. Die eksklusivis bevind haar dus hier voor 'n dilemma: òf sy laat vaar die veronderstelling dat God Homself uitsluitlik in en deur Jesus Christus reddend openbaar het, òf sy laat vaar die veronderstelling dat God 'n almagtige, volmaak liefdevolle en regverdige God is. Hierdie dilemma word gewoonlik op een van drie maniere deur Christene beantwoord.

'n Eerste antwoord wat deur onder andere Kraemer en Newbigin gegee word, lui dat ons nie kan weet of diegene gered word wat nie van Jesus Christus gehoor het nie. Hierdie aangeleentheid moet gewoon aan die "wysheid en genade van God" en die (vir ons) "onbegryplike of misterieuse aktiwiteit van sy Gees" oorgelaat word (vgl. Newbigin 
1981:20; Kraemer 1939:4; D’Costa 1986:68). Hierdie antwoord leun swaar op teologiese voorveronderstellings wat reeds heelwat kritiek ontlok het. Dit gaan hier egter spesifiek om die vraag of twee van hierdie voorveronderstellings wel kohereer. Die eerste lui dat verlossing/ redding/bevryding slegs deur Jesus Christus verkry kan word. Die ander lui dat God 'n almagtige, liefdevolle en regverdige God is wat nie wil hê dat enigiemand verlore gaan nie, maar dat almal gered moet word. Kraemer en Newbigin se antwoord slaag myns insiens alleenlik daarin om bovermelde dilemma te omseil, indien ons daarby sou veronderstel dat God uiteindelik wel op een of ander wyse toesien dat diegene gered word wat nie van Jesus Christus gehoor het nie. In terme van die voorveronderstellings van Kraemer en Newbigin sou hierdie wyse inderdaad "misterieus" moes wees, aangesien dit kennelik onafhanklik van 'n gelowige aanvaarding van die soenverdienste van Christus sou moes geskied. Dit laat 'n mens egter wonder waarom Jesus Christus in die eerste plek nodig was. Verder kan "misterieuse wyse" hier teoreties op enige wyse dui wat nie met die soenverdienste van Jesus Christus verband hou nie. Dit sou byvoorbeeld ook kon dui op die feit dat God mense via die praktyke en oortuigings van nie-Christelike godsdienste van hul sonde red of verlos. Sou Kraemer en Newbigin bereid wees om hierdie moontlikheid ernstig te oorweeg? Ek twyfel. Trouens, in die lig van wat in die voorafgaande oor die standpunt van Kraemer gesê is, sou hy veel eerder die praktyke en oortuigings van nieChristelike godsdienste reken tot die sonde waarvan mense verlos moet word! Sê D'Costa tereg:

Kraemer, Newbigin and others seem to want to relieve this exclusivist internal tension [vgl. bovermelde dilemma] without paying the price in terms of the theological implications of their answer (1986:68).

'n Tweede antwoord, wat ten nouste by die eerste aansluit, lui dat diegene wat nooit van Christus gehoor het nie, ná hul dood met Hom gekonfronteer sal word en dat hul dan die geleentheid sal kry om vir of teen Christus te kies (vgl. Braaten 1977:117; Knitter 1985:117; D'Costa 1986:9, 68). In teenstelling met die antwoord wat hierbo bespreek is, ondermyn hierdie antwoord nie die noodsaak van 'n gelowige aanvaarding van die soenverdienste van Jesus Christus ten einde gered te word nie. Dit ontken egter wel die noodsaak van só 'n aanvaarding in hierdie (voordoodse) lewe en weerspreek as sodanig een van 
die sentrale religieuse oortuigings van heelwat (die meeste?) Christene. Die oortuiging dat só 'n aanvaarding reeds nóú belangrik is, berus dikwels op die veronderstelling dat dit nou reeds tot 'n "oorvloedige" lewe (vgl. Johannes 10:10; Prozesky 1991:42) sal lei en dat 'n lewe daarsonder "leeg" en "betekenisloos" is. Hierdie veronderstelling gee egter opnuut aanleiding tot die vraag waarom 'n almagtige, volmaak liefdevolle en regverdige God nie toesien dat alle mense nou reeds hierdie "oorvloedige" lewe smaak nie. Indien God inderdaad almagtig, volmaak liefdevol en regverdig is, waarom sou Hy dan toelaat dat die oorgrote meerderheid van mense 'n "betekenislose" lewe lei en hul dan eers ná hul dood 'n kans op die "oorvloedige" lewe bied?

Die derde antwoord wat gewoonlik op bovermelde dilemma gegee word, kom neer op 'n aansienlike afswakking van die eksklusivistiese soteriologie. Hierdie antwoord word allerweë bestempel as die "inklusivistiese" benadering tot die probleem van verskillende godsdienste se botsende aansprake op waarheid. Vervolgens meer oor hierdie benadering aan die hand van die Katolieke teoloog, Karl Rahner.

\section{INKLUSIVISME: RAHNER}

'n Eerste fundamentele veronderstelling van Karl Rahner se standpunt ten opsigte van die waarheid van nie-Christelike godsdienste lui dat dit inderdaad God se begeerte is dat alle mense gered moet word en dat niemand verlore moet gaan nie. Dit beteken vir Rahner dat God ook sal toesien dat alle mense gered word of gered sou kon word. 'n Tweede fundamentele veronderstelling van die standpunt van Rahner lui dat redding of verlossing slegs in en deur God se geopenbaarde genade kan geskied. Op grond van hierdie geopenbaarde genade kan die Christelike godsdiens sigself met reg verstaan as "the absolute religion, intended for all men, which cannot recognize any other religion beside itself as of equal right" (Rahner 1981:56 — my klem). Of, soos Rahner dit ook stel:

Since the time of Christ's coming - ever since he came in the flesh as the Word of God in absoluteness and reconciled, i.e. united the world with God by his death and resurrection ... Christ and his continuing historical presence in the world (which we call "Church") is the religion which binds man to God (1981:57). 
Dit beteken egter nie vir Rahner dat God Homself nie ook aan nieChristene openbaar en tewens reddend openbaar nie. Rahner verduidelik die aard van hierdie reddende openbaring met verwysing na 'n sogenaamde "super-natuurlike eksistensiaal" of "supernatural existential". ${ }^{13}$ Hierdie begrip dui, kortom, op die menslike natuur soos "verhoog" ("elevated") ${ }^{14}$ deur God se openbaring. Hierdie "verhoging" bied aan die mens die kapasiteit om God se reddende genade (dit is God self) ${ }^{15}$ te ontvang. Of, soos Rahner dit stel:
Man should be able to receive this Love which is God himself; he must have a congeniality for it. He must be able to accept it (and hence grace, the beatific vision) as one who has room and scope, understanding and desire for it. Thus he must have a real "potency" for it. He must have it always (1975b:187). ${ }^{16}$

Let op die uitspraak: "He must have it always". Met hierdie uitspraak onderstreep Rahner sy opvatting dat die menslike natuur nie anders as 'n "supernatural existential" verstaan moet word nie, resp. "Our actual nature is never 'pure' nature" (1975a:183); “'Nature'... as the concept contraposed to the supernatural, is consequently a remainder concept [Restbegriff]" (1975b:189). Hierdie status van die menslike natuur is volgens Rahner nie afhanklik van, of vereis nie dat die mens homself/haarself spesifiek só, dit is as "supernatural existential", moet verstaan nie. Hy skryf: "man ... (consciously or unconsciously) is subject to the influence of the supernatural existential ..." (Rahner 1975b: 189). As sodanig word God se reddende genade via 'n verskeidenheid van alledaagse, dog uitsonderlike ervarings aan die mens geopenbaar. Onder hierdie ervarings tel byvoorbeeld die ervaring van "infinite

13 Vergelyk Rahner (1961:300-302, 310-315), opgeneem in McCool (1975:185190). Vergelyk ook Rahner (1978:126-133), opgeneem in Hodgson \& King (1985:104-108); asook Rahner (1961:360-366, 368-369; 1963:44-53; 1966: 166-169, 174-184; 1967:86-89), opgeneem in McCool (1975:175-184, 191-204).

14 Vergelyk Rahner (1981:66).

15 Vergelyk:

Grace is God himself, the communication in which he gives himself to man as the divinizing favour which he is himself (Rahner 1975a:179).

16 Vergelyk in hierdie verband ook Rahner se begrip van "ready hearers", dit is "hoorders" wat ontvanklik of "gereed" vir God se openbaring is (1969b:130-180). 
longings", van "radical optimism", van "the radical protest against death", van 'n "radical guilt" en 'n "still abiding hope", asook

the experience of being confronted with an absolute love precisely where it is lethally incomprehensible and seems to be silent and aloof... (Rahner 1975a:184). ${ }^{17}$

Al hierdie en soortgelyke ervarings van wat miskien samevattend bestempel sou kon word as die transendering of oorskryding van die "negatiewe" of "verkeerde" in die rigting van dit wat "reg, goed en mooi" is, dui op die feit dat 'n "transcendental revelation" (vgl. Rahner 1978: 138 e.v.) volledig deel van ons natuur is. Of, soos Knitter dit stel:

Every time we reach out beyond ourselves, to what is true and good, we are experiencing and responding to grace; we are experiencing and truly knowing God even though this knowledge may be "unreflexive" or "unthematic", not yet objectified ... To know God in these different ways is for Rahner not just revelation. It includes salvation: a communion with the one true God, an experience of purpose, peace and growth for the individual and society (Knitter 1985:125-126; vgl. ook Rahner 1969a:390-398).

Tot sover die eerste belangrike "skuif" of premis in die argument van Rahner: God wil alle mense red en daarom stel Hy ook sy reddende genade aan alle mense beskikbaar. Soos hy dit kortom stel: "There is also grace outside the Church and its sacraments" (Rahner 1975a:181). Die konklusie wat Rahner uiteindelik wil begrond, betref egter nie soseer die feit dat daar aan alle mense (resp. individue) 'n kans op redding/verlossing gebied word nie. Rahner het dit spesifiek oor die soteriologiese kapasiteit of "saving value" van nie-Christelike godsdienste. Vandaar sy tweede belangrike "skuif" of premis. Hierdie premis lui dat die mens essensieel 'n sosio-historiese natuur het en dat God se aanbod van genade daarom noodwendig een of ander sosio-historiese vorm moet aanneem. Sulke sosio-historiese vorme of mediums van God se reddende genade vind hy in die godsdienste:

$[\mathrm{H}]$ uman existence as such, the nature of religion itself must include a social constitution - which means that religion can exist only in a social form. This means, therefore, that man, who is commanded to have a religion, is also commanded to seek and accept a social form of religion (Rahner 1981:59-60); ... by the fact that in practice

17 Rahner lys ook ander "ervarings van genade". Vergelyk in hierdie verband ook Knitter (1985:125-126). 
man as he really is can live his proferred relationship to God only in society, man must have had the right and indeed the duty to live his relationship to God within the religious and social realities offered to him in his particular historical situation (Rahner 1981:74-75).

Op grond van hierdie twee premisse, te wete dat God sy reddende genade aan alle mense openbaar en dat hierdie openbaring via die godsdienste geskied, konkludeer Rahner nou dat ook nie-Christelike godsdienste daarom met reg as "lawful religions" beskou kan word "without thereby denying the error and depravity contained in it [dit is in die nie-Christelike godsdienste]" (1981:61). ${ }^{18}$ As "lawful religions" bevat nie-Christelike godsdienste "supernatural elements arising out of the grace which is given to men as a gratuitous gift on account of Christ" (Rahner 1981:61):

A lawful religion means here an institutional religion whose "use" by man at a certain period can be regarded on the whole as a positive means of gaining the right relationship to God and thus for the attaining of salvation, a means which is therefore positively included in God's plan of salvation (Rahner 1981:66-67).

Só verstaan, is 'n lid van 'n "ekstra-Christelike" (1981:75) godsdiens vir Rahner niks minder as 'n "anonieme Christen" nie. Hy is 'n "Christen" in soverre God se reddende genade aan hom geopenbaar is en in soverre alle redding/verlossing in en deur Christus geskied (vgl.: "this salvation which reaches him... is Christ's salvation, since there is no other salvation..."). ${ }^{19} \mathrm{Hy}$ is 'n "anonieme" Christen in soverre hy hierdie "goddelike gawe van genade ongereflekteerd en implisiet aanvaar" (vgl. Rahner

18 Op die beswaar dat hierdie "error and depravity" godsdienste diskwalifiseer as mediums van God se genade, antwoord Rahner dat die Ou Testament op talle gebreke in die Joodse religieuse tradisie wys en tog word hierdie tradisie deur Christelike teoloë as 'n medium van God se openbaring erken. Sy punt is dat 'n godsdiens nie foutloos hoef te wees om as 'n medium van God se openbaring te dien nie. In die laaste instansie moet die individuele gelowige self die kaf van die koring skei. Rahner skryf:

[I]t was — in the last analysis - left to the conscience of the individual Israelite himself to differentiate between what in the concrete appearance of the Israelitic religion was the true covenant with God and what was a ... corruption of this God-instituted religion (1981: 68; vgl. ook 1981:67-69, 74).

19 Rahner (1981:76 — my klem). Vergelyk ook Rahner (1978:311 e.v.). 
1981:77), dit is in soverre hy hierdie gawe nie eksplisiet as 'n gawe van God in en deur Christus dui nie. Rahner skryf:

[If] he has already accepted this grace as the ultimate, unfathomable entelechy of his existence by accepting the immeasurableness of his dying existence as opening out into infinity [vgl. die "supernatural existential"] - then he has already been given revelation in a true sense even before he has been affected by missionary preaching from without. For this grace, understood as the a priori horizon of all his spiritual acts, accompanies his consciousness subjectively, even though it is not known objectively (1981:75).

Hiermee wil Rahner in die eerste plek nie sê dat sendingwerk (dit is die "explicit preaching of Christianity") oorbodig geword het nie. Die individu

who grasps Christianity in a clearer, purer and more reflective way has, other things being equal, a still greater chance of salvation than someone who is merely an anonymous Christian (Rahner 1981:76-77). ${ }^{20}$

Sendingwerkers moet egter steeds in gedagte hou dat die lede van ekstra-Christelike tradisies nie "absoluut onbekend" (Rahner 1981: 75 ) is met die evangelieboodskap nie:

[T]he proclamation of the Gospel does not turn someone absolutely abandoned by God and Christ into a Christian, but turns an anonymous Christian into someone who now also knows about his Christian belief in the depths of his grace endowed being by objective reflection and in the profession of faith which is given a social form in the Church (Rahner 1981:76; vgl. ook 1975a:183; 1981:77).

Tweedens moet sy gebruik van die benaming "anonieme Christen" volgens Rahner hoegenaamd ook nie as 'n teken van Christelike hoogmoed jeens ander godsdienste vertolk word nie. Inteendeel, hierdie benaming getuig eerder vir Rahner van 'n optimisme (vgl. 1981:6465) oor die redding/verlossing van die lede van "ekstra-Christelike" tradisies. Só deurbreek dit die tradisioneel eksklusivistiese en veroordelende houding van Christene jeens hierdie tradisies. Die etiket "anonieme Christen" dwing beskeidenheid van die Christen en die Kerk

20 Volgens Knitter het verwysings na die "greater personal privilege" (1985:130) van (belydende) Christene by Rahner later plek gemaak vir'n groter klem op die verantwoordelikheid wat Christene ten opsigte van die welsyn van ander het. Vergelyk ook Knitter (1985:132). 
af "[f]or it is a profound admission of the fact that God is greater than man and the Church" (Rahner 1981:79):

$[T]$ he Church will not so much regard herself today as the exclusive community of those who have a claim to salvation but rather as the historically tangible vanguard and the historically and socially constituted explicit expression of what the Christian hopes is present as a hidden reality even outside the visible Church (Rahner 1981:77).

In die derde en laaste plek sou dit 'n growwe fout wees om in die lig van Rahner se begrip van "anonieme" Christenskap te konkludeer dat hy sy opvattings insake die normatiewe status van die Christelike godsdiens (vis-à-vis ander godsdienste) prysgegee het. Alhoewel daar "supernatural, grace-filled elements" in nie-Christelike godsdienste is, bly die Christelike godsdiens steeds vir Rahner die "absolute" godsdiens, dit is bly dit steeds vir hom die kriterium of norm in die lig waarvan genoemde elemente pas in ander godsdienste geïdentifiseer kan word. Of, kortom, die Christelike godsdiens bly steeds vir Rahner die kriterium in die lig waarvan ander godsdienste beoordeel moet word. Hierbo het ons gesien dat alle reddende genade volgens hom genade van Christus is. God se reddende openbaring, sê Rahner, "rests on the Incarnation, death and resurrection of the one Word of God become flesh" (1981:56). Daarom bly alle nie-Christelike godsdienste — ten spyte van hul "supernatural elements" — onaf, onvolledig of onvoltooid totdat hulle hul ware identiteit en volle verlossing of vervulling in Christus of die Kerk as liggaam (sigbare kontinuering) van Christus gevind het. Rahner stel dit trouens duidelik dat die nie-Christelike godsdienste hul soteriologiese kapasiteit of legitimiteit as mediums van God se reddende genade verloor sodra hul met die evangelie gekonfronteer word:

We are here concerned with dogmatic theology and so can merely repeat the universal and unqualified verdict as to the unlawfulness of the non-Christian religions right from the moment when they came into real and historically powerful contact with Christianity ... (1981: 62; vgl. ook 1981:59-60). ${ }^{21}$

21 Die opvatting dat 'n konfrontasie met die Christelike godsdiens die nie-Christelike (dit is anoniem Christelike en as sodanig "lawful") godsdienste "unlawful" maak, impliseer egter dat dit vir nie-Christene — in soverre dit hul verlossing betref - beter of "veiliger" sou wees om liewer nooit met die Christelike godsdiens gekonfronteer te word nie! Soos Owen Thomas tereg opmerk: 
Die standpunt van Rahner verwoord in 'n mindere of meerdere mate steeds die benadering van die meerderheid van Katolieke teoloë wat hul bemoei met die probleem insake die verhouding tussen die Kerk of die Christelike godsdiens en die nie-Christelike godsdienste. ${ }^{22}$ Verder kan die invloed van Rahner ook duidelik bespeur word in die Katolieke ekklesiologie sedert Vatikaan II (vgl. Knitter 1985:130). Min mense sou ontken dat die standpunt van Rahner'n duidelike afswakking van die bekende extra Ecclesiam nulla salus (dit is die Katolieke weergawe van die konserwatiewe eksklusivistiese standpunt ${ }^{23}$ ) is. In die lig van die voorafgaande behoort dit egter duidelik te wees dat sy akkommoderende of inklusiewe houding jeens nie-Christelike godsdienste hoogstens as 'n gedeeltelike en voorlopige goedkeuring van hierdie godsdienste bestempel sou kon word. Volgens Rahner bly dit steeds die Christen se opdrag om van anonieme Christene lidmate van die Kerk te maak, dit is om van hulle belydende of eksplisiete Christene te maak. Eers dan sal hulle die "volle" verlossing smaak waarna hul implisiet hunker. Uiteindelik is die nie-Christelike godsdienste niks meer as praeparatio evangelica ('n voorbereiding vir die evangelie) nie (vgl. Knitter 1986:101; Heim 2001:215-216).

Só verstaan, is Rahner se idee van "anonieme” Christenskap egter weinig meer as 'n deursigtige teologiese maneuver om die Katolieke standpunt dat geen verlossing buite die Kerk moontlik is nie, van niksseggendheid te red. Op hierdie punt is ek dit met die Katolieke teoloog, Hans Küng, volledig eens. Ten opsigte van die idee van "anonieme" Christenskap vra Küng:

[I]s not the whole of good-willed humanity thus swept with an elegant gesture across the paper-thin bridge of a theological fabrication into the back door of the "holy Roman Church", leaving no one of good

[I]n this view [dit is die bovermelde standpunt van Rahner insake die "unlawfulness" van nie-Christelike godsdienste wanneer hul met die Christelike godsdiens gekonfronteer word] ... the only serious possibility of the loss of the ultimate fulfillment lies in the rejection of the Christian gospel. Thus it might be safer for the adherents of other religions if the Christian message were kept secret! (1969:24).

22 Vergelyk in dié verband die werk van onder andere Edward Schillebeeckx, Pietro Rossano, Avery Dulles, Richard McBrien (vgl. Knitter 1986:101).

23 Vergelyk Küng (1969:199 e.v.) en Knitter (1986:99-100). 
will "outside"? The formula, "no salvation outside the Church", is then as true as ever, because all in fact are in the Church from the very beginning: not as formal, but as "anonymous" Christians or - as we ought logically to say — "anonymous Roman Catholics” (1976:98).

As sodanig klop die idee van anonieme Christenskap nie met Küng se ervaring van nie-Christelike godsdienste nie. Küng weet byvoorbeeld van geen opregte, self-respekterende Boeddhis, Jood of Moslem wat na volle lidmaatskap van die Kerk hunker nie, of wat die veronderstelling dat hy/sy 'n anonieme Christen is, nie as uiters verwaand sou beskou nie. Hoe sou Christene immers reageer op die bewering dat hulle, byvoorbeeld, anonieme Boeddhiste is, selfs al word dit met die beste bedoelings ter wêreld beweer? Hierbenewens ondermyn die idee van anonieme Christenskap volgens Küng die eiesoortigheid of uniekheid van Christus en die Kerk. 'n Kerk wat orals is, is immers nêrens. Só word dit juis niksseggend om te beweer dat geen verlossing buite die Kerk moontlik is nie:

Are we not thus in danger ... of diminishing the reality of Christianity merely to save an infallible formula? ... [A]re we not making the Church equivalent to the world, Christendom to humanity? Does not Christianity thus become a religious luxury and the Christian ethos superfluous? ... [D]oes not Jesus in the last resort become all too easily an avatar for the Hindus, a bodhisattva for the Buddhists, one of the prophets for the Muslims? (Küng 1976:98). ${ }^{24}$

\section{SLOTOPMERKINGS}

Die "verwaandheid" waarop Küng wys, is nou verwant aan 'n belangrike eienskap wat die inklusivistiese benadering van Rahner in gemeen het met sowel die konserwatiewe eksklusivistiese benadering van Barth as die liberale eksklusivistiese benaderings van Kraemer en Brunner. Sowel die inklusivis as die konserwatiewe en liberale eksklusivis verabsoluteer naamlik dogmaties en willekeurig hul eie religieuse tradisie tot die norm vir ander religieuse tradisies. In die proses diskwalifiseer

24 Alhoewel Küng hom eers in Christ sein (1974) behoorlik of met omhaal teen Rahner se idee van anonieme Christenskap uitspreek, kan kritiek op hierdie idee reeds in 'n bundel van sy essays, Freedom today (1966), aangetref word (vgl. Küng 1969: 203, 215). Ek konsentreer hier spesifiek op een van hierdie essays, te wete The freedom of religions, soos opgeneem in Thomas (1969:193-217). 
hulle van huis uit die aansprake op waarheid van ander religieuse tradisies en lewer so die waarheid van godsdienste resloos uit aan die subjektiewe willekeur wat hulle juis wou vermy. Wat verhoed die lede van ander religieuse tradisies immers om op soortgelyke wyse húl tradisies dogmaties en willekeurig tot die norm vir ander religieuse tradisies te verhef?

Hiermee is nie gesê dat die eksklusivistiese en inklusivistiese benaderings noodwendig of ongekwalifiseerd "immoreel" en "onverdraagsaam" is nie, respektiewelik dat die eksklusivis aan geen andersgelowige die reg of die ruimte gun om sy of haar religie te beoefen nie. Kritiek op die "dogmatisme" van die eksklusivistiese en inklusivistiese benaderings gaan dikwels gepaard met die veronderstelling dat hierdie benaderings noodwendig op die (gewelddadige) onderdrukking van die ander neerkom en dat hulle as sodanig by voorbaat interreligieuse samewerking (byvoorbeeld vir een of ander verdienstelike saak) en vreedsame naasbestaan uitsluit (vgl. Netland 1985:75; 1988:242-246; 1991:302-303). Myns insiens is daar egter geen noodwendige verband tussen hierdie benaderings en sodanige onverdraagsaamheid nie, hoewel eksklusivisme en inklusivisme (soos dit hierbo verduidelik is) dikwels daartoe aanleiding gee. Op hierdie punt skaar ek my by 'n opmerking van Gavin D'Costa insake die eksklusivistiese benadering van Kraemer:
Against some often misdirected charges levelled by pluralists against Kraemer, it must be emphatically stated that Kraemer constantly and consistently accepts the following as concomitant with the exclu- sivist position: practical cooperation - medical, educational and social service; religious tolerance when it means "that everybody should have a fair chance to present his case, but not that nobody should ardently believe in his case" (1986:57).

Hoe dit egter ook al sy, my kritiek op die eksklusivistiese en inklusivistiese benaderings betref die sin waarin hierdie benaderings wel met reg as "absolutisties" of "onverdraagsaam" bestempel kan word. Hierdie benaderings is naamlik "absolutisties" en "onverdraagsaam" in soverre hulle by voorbaat nie die aansprake op waarheid van ander godsdienste akkommodeer nie. Sowel die eksklusivis as die inklusivis voorveronderstel gewoon dogmaties en willekeurig dat hulle bepaalde godsdiens as die norm vir alle ander godsdienste moet dien. 
Kan dié willekeur wel vermy word? Kan die waarheid van godsdienste wel nie-arbitrêr of objektief beoordeel word en, indien wel, in die lig van watter kriteria? Is die waarheid van religieuse tradisies nie tog maar aan subjektiewe willekeur uitgelewer nie? Ruimte laat my nie toe om dié vrae hier behoorlik te beantwoord nie. Die objektiewe beoordeling van die godsdiens van 'n ander vereis in die eerste plek 'n behoorlike begrip daarvan, d.w.s. dit vereis dat die beoordelaar kommunikeer met diegene wat beoordeel word (vgl. Louw 2000a: 255-278). Hierbenewens vereis dit ook 'n beoordelingskaal waarmee alle betrokkenes hul kan vereenselwig (vgl. Louw 2000b:45-73). Kortom, die objektiewe beoordeling van godsdienste vereis 'n gemeenskaplike "taal". Hierdie "taal" is nie 'n gegewe nie, maar'n opgawe. Dit bestaan, indien hoegenaamd, op grasie van 'n volgehoue blootstelling aan die ander. Dit vereis 'n volgehoue bereidheid om aandagtig na hom/haar te luister om só noukeurig moontlike ooreenkomste en verskille met hom/haar te identifiseer. Die proses waarin genoemde gemeenskaplike "taal" gevorm word, kom neer op 'n wisselwerking tussen en uiteindelike versmelting van horisonne. Natuurlik impliseer die voorlopigheid en veranderlikheid van die "taal" wat gelowiges praat, dit is van die terme waarin hulle hulself en die ander verstaan en beoordeel, dat so 'n versmelting nie altyd sal geluk nie. Dit beteken egter ook dat so 'n versmelting nie outomaties of met voorspelbare reëlmaat sal misluk nie. Inteendeel, die voorlopigheid en veranderlikheid van die "taal" van gelowiges beteken juis dat hierdie versmelting dalk op 'n dag iewers sou kon geluk (vgl. Brand 2002:35-36). Hierdie feit weerhou gelowiges daarvan om òf hul eie godsdiens dogmaties en onkrities tot die norm vir ander godsdiens te verabsoluteer, òf die evaluering van godsdienste gewoon aan subjektiewe willekeur oor te laat. 


\section{BIBLIOGRAFIE}

AlBERTS L

2002. Is Jesus Christ unique? Vereeniging: Christian Art.

BARTH K

1956. Church dogmatics I/2. [1938]. (Vertalers: G.T. Thomason \& H. Knight.)

Edinburgh: T. \& T. Clark.

1961. Church dogmatics IV/3. Edinburgh: T. \& T. Clark.

1985. Critique of Christianity as a religion. In: P.C. Hodgson \& R.H. King (eds.), Readings in Christian theology (Philadelphia: Fortress Press).

BRAATEN C E

1977. The flaming center: a theology of the Christian mission. Philadelphia: Fortress.

1992. No other gospel! Christianity among the world's religions. Minneapolis: Fortress.

BRAND G

2002. Speaking of a fabulous ghost: in search of theological criteria, with special reference to the debate on salvation in African Christian Theology. Frankfurt am Main: Peter Lang.

BRUNNER E

1946. Revelation and reason: the Christian doctrine of faith and knowledge. (Vertaler:

O. Wyon.) Philadelphia: Westminster.

1969. Revelation and religion. In: O.C. Thomas (ed.), Attitudes toward other religions: some Christian interpretations. London: SCM.

D'Costa G

1986. Theology and religious pluralism. Oxford/New York: Basil Blackwell.

\section{Heim S M}

2001. The depth of the riches: A trinitarian theology of religious ends. Grand Rapids, Michigan: Wim B. Eerdmans.

Hick J \& HebBlethwaite B (EDs.)

1981. Christianity and other religions. Philadelphia: Fortress.

Hodgson, Peter C. \& King, Robert H (Eds.)

1985. Readings in Christian theology. Philadelphia: Fortress.

\section{KNITTER P F}

1985. No other name? A critical survey of Christian attitudes toward the world religions. London: SCM.

1986. Catholic theology of religions at a crossroads. In: H. Küng \& J. Moltmann (eds.), Christianity among world religions. Edinburgh: T. \& T. Clark.

\section{KRAEMER H}

1938. The Christian message in a non-Christian world. London: Edinburgh House. 1939. Continuity or discontinuity. In: W. Paton (ed.), The authority of faith (London: Humphrey Milford, and Oxford: Oxford University Press, Tambaram Series 1). 1956. Religion and the Christian faith. London: Lutterworth. 
1960. Waarom nu juist het Christendom? Nijkerk: G.F. Callenbach N.V.

\section{KÜNG H}

1966. Freedom today. New York: Sheed Ward.

1969. The freedom of religions. In: O.C. Thomas (ed.), Attitudes toward other religions: some Christian interpretations (London: SCM).

1974. Christ sein. München: Piper Verlag.

1976. On being a Christian. (Vertaler: E. Quinn.) New York: Doubleday.

\section{LOUW D J}

1995. Pluralisme en konflik: Die probleem van verskillende godsdienste se botsende aansprake op waarheid. Doktorale proefskrif. Universiteit van Stellenbosch. (Ongepubliseerd.)

2000a. Oor die moontlikheid van interreligieuse kommunikasie. South African Journal of Philosophy 19(3):255-278.

$2000 \mathrm{~b}$. On evaluating religions: beyond objectivism and relativism. Theologia Viatorum: Journal of Theology and Religion in Africa 26:45-73.

McCoOl G A (ED.)

1975. A Rahner reader. London: Darton, Longman \& Todd.

\section{Mulder D C}

1986. "None other gods" — " no other name". The Ecumenical Review 38(2):209-215. 1989. The dialogue between cultures and religions: Kraemer's contribution in the light of later developments. The Ecumenical Review 41:13-19.

\section{NeTLAND H A}

1985. Religious pluralism and truth. Trinity Journal 6:74-86.

1988. Exclusivism, tolerance, and truth. Evangelical Review of Theology 12:240-260. 1991. Dissonant voices: religious pluralism and the question of truth. Grand Rapids, Michigan: William B. Eerdmans.

\section{Newbigin L}

1981. The basis, purpose and manner of interfaith dialogue. In: R. Rousseau (ed.), Interreligious dialogue (Montrose: Ridge Row).

1988. A sermon preached at the thanksgiving service for the fiftieth anniversary of the Tambaram conference of the International Missionary Council. International Review of Mission 78(307):327-333.

\section{PROZESKY M}

1991. The challenge of other religions for Christianity in South Africa. Journal of theology for Southern Africa 74:35-45.

\section{RACE A}

1982. Christians and religious pluralism: patterns in the Christian theology of religions. Maryknoll, New York: Orbis Books.

\section{RAHNER K}

1961. Theological investigations (vol. I). London: Darton, Longman \& Todd. 
1963. The Christian commitment. New York: Sheed and Ward.

1966. Theological investigations (vol. IV). London: Darton, Longman \& Todd.

1967. Theological investigations (vol. III). London: Darton, Longman \& Todd.

1969a. Theological investigations (vol. VI). London: Darton, Longman \& Todd.

1969b. Hearers of the Word. (Vertaler: M. Richards.) New York: Herder and Herder.

1975a. Nature and grace. In: G.A. McCool (ed.), A Rabner reader (London: Darton, Longman \& Todd).

1975b. Relationship between nature and grace: the supernatural existential. In: G.A. McCool (ed.), A Rahner reader (London: Darton, Longman \& Todd).

1978. Foundations of Christian faith: an introduction to the idea of Christianity. (Vertaler: W.V. Dych.) London: Darton, Longman \& Todd.

1981. Christianity and the non-Christian religions. In: J. Hick \& B. Hebblethwaite (eds.), Christianity and other religions (Philadelphia: Fortress).

\section{THOMAS O C (ED.)}

1969. Attitudes toward other religions: some Christian interpretations. London: SCM.

\section{WARREN R}

2002. The purpose driven life. Grand Rapids, Michigan: Zondervan.

Trefwoorde

Religieuse pluraliteit

Waarheid

Eksklusivisme

Inklusivisme
Keywords

Religious pluralism

Truth

Exclusivism

Inclusivism 